\title{
The World After September 11th: Change and Continuity ${ }^{1}$
}

\author{
Tomas Jermalavicius ${ }^{2}$
}

September 11th, 2001 has become the date used most frequently by the media, diplomats, politicians, the military, academics, and ordinary citizens across the world both when discussing current affairs and trying to anticipate what the future holds. The horrendous terrorist attacks against the United States perpetrated on that day have profoundly shocked the world community. The destruction of the World Trade Center in New York and a part of the Pentagon building in Washington D.C., with the loss of more than 3,000 lives, were the first attacks against the United States on U.S. soil since the Japanese surprise attack against Pearl Harbor on December 7th, 1941, and were even more outrageous given that the absolute majority of the casualties were civilians. Just as in the wake of Pearl Harbor, the September atrocities set the United States on the path of war, this time against both the global Al-Qaeda terrorist network led by the pariah Saudi dissident Osama bin Laden, who allegedly masterminded these atrocities and offered support for their execution, and against the regimes which harbored or sponsored the terrorist groups.

Soon after the attacks, the United States, having secured the backing of a broad international coalition and assisted by its allies, launched a multidimensional campaign with the aim of disrupting Al-Qaeda, capturing Osama bin Laden, and dissuading the so-called "rogue states" from further pursuit of policies in support of international terrorism. The Taliban regime in Afghanistan, which has been hosting bin Laden and his training camps for the past several years, became the first target of the war on terrorism, as the U.S. deployed its formidable air power against the Taliban military assets and infrastructure and, in conjunction with the offensive of the Afghan opposition on the ground, succeeded in evicting the Taliban from power. The war goes on and probably will continue on different fronts and in different theaters for a long time to come. Its outcome and effects remain to be seen. However, while bearing in mind the uncertainty that war brings into world affairs, the implications of the events of September 11 can already be assessed and generalized with a measure of confidence.

This article will explore the ways that September 11 has already influenced and still can affect world politics in the future. It will attempt to provide some perspectives on the factors these events have brought or can possibly bring into the realm of international relations and what are the implications to the international system as a whole and to the processes within it. The major aim of such an

\footnotetext{
${ }^{1}$ Tomas Jermalavicius is the Assistant Professor and Vice Dean of the Institute of Defense Studies, Baltic Defense College, Tartu, Estonia.

${ }^{2}$ This article was first published in the Baltic Defence Review No. 6, 2001.
} 


\section{THE QUARTERLY JOURNAL}

effort is to clarify whether September 11th should be considered as a new departure point in world politics, where one can start talking of different characteristics of the international system, new dynamics of processes in this system, and a new quality of international relations compared to the state of affairs prior to September 11. The reason for addressing this issue is that developments in the aftermath of the terror attacks in the United States have led many to believe that September 11 heralds the dawn of a new era in international relations and that a completely new world order is likely to take shape as a result. ${ }^{3}$ Significant shifts in the policies of the major actors such as the U.S. or Russia, as well as ensuing revisions of security policies, may indeed justify this interpretation. By some accounts, the more worrisome isolationist manifestations of U.S. foreign policy, especially with regard to regional conflicts across the globe, and the more unilateral instincts of the U.S. administration arguably have been replaced with the policies of deep engagement and multilateralism. At the same time, Russia has made an impressive U-turn from being more or less antagonistic vis-à-vis the West to seeking rapprochement with the West, if not lasting integration into it. These are just a few aspects of the developments that have taken place since the terrorist attacks that provoke thoughts about fundamental change on the global scene. The psychological shock also adds to the tendency to adopt a stand where the world is looked at through different eyes than before the attacks.

Legitimate as it may seem, however, interpreting September 11 as a new point of departure for the functioning of the entire international system and the conduct of international relations can prove a too radical and, at the same time, a somewhat simplistic way of conceptualizing the importance of the events of September 11. While acknowledging the new facets of world politics brought to light by the terrorist attacks, the paper will argue that their impact should rather be assessed in the light of developments preceding them, dating back to the end of the Cold War, when the bipolar international system collapsed and the new world order started taking shape. This perspective would thus interpret September 11 as being the most instructive and the sharpest symptom reflecting the characteristics of the post-Cold War international environment that we have experienced so far, rather than a trigger of entirely new processes leading to disintegration of the current architecture of world politics. To a certain extent, September 11 has removed some of the ambiguities about the world we are facing, while at the same time introducing other uncertainties that are reinforced by the war on terrorism and the results it may produce. In addition, this paper will supplement this conceptual approach with an interpretation of the September 11 attacks as the event that accelerated and catalyzed processes that had been in motion for some time already. In accomplishing this task, the inquiry will compare post-September 11

\footnotetext{
${ }^{3}$ See Dominique Moisi, "Welcome to the New, New World Order," Financial Times, September 13, 2001.
} 
developments, frequently cited as an indication of the upcoming dramatic changes in the world system, with the environment that had emerged since the end of the Cold War. It will address the major underlying questions, such as: To what extent have the characteristics of the post-Cold War international system been altered (or not affected) by September 11? Was the post-September 11 pattern of interaction between the actors in this system indiscernible prior to the attacks, and therefore completely new? Have any significant modifications been made in a way that the nature of conflict within the system is understood? It is these three interrelated areas-the international system, international relations, and international conflict—which will constitute an organizing analytical framework for addressing these questions.

By looking for the connections between the post-September 11 events and the processes in place before the attacks, the paper will largely ignore the strategic issues of the ongoing war on terrorism, although the already visible effects of the war will come into play in the discussion. The military realm as such remains beyond the scope of this inquiry, as do the more or less conspicuous shifts in domestic politics and social attitudes in the U.S. or its allies since the commencement of this war. Omitting the latter from the analysis certainly makes this effort less comprehensive. However, it rests on the assumption that, as profound as their effects might be, domestic developments do not translate directly into changes in the international environment, although they can facilitate them and serve as one of the sustaining factors for a specific mode of international relations. Finally, the effects of the terrorist attacks upon the prevailing security paradigm will not be examined, on the premise that the events of September 11 have not induced any significant changes in this area, since terrorism and related threats, such as proliferation of weapons of mass destruction, have already been incorporated into the general notion of comprehensive security, which obviously will not be revisited.

The first part of the paper will provide an overview of the post-Cold War international setting prior to September 11th. The argument that the international system became unipolar after the collapse of the Soviet Union and that the U.S. has been acting as a hegemon in the international system ever since will be central, and will lay the groundwork for placing September 11 into a broader context. The major lines of international conflict in the post-Cold War environment will be elaborated here, including some discussion of a model suggested by Samuel Huntington known as the theory of the "clash of civilizations." This account will build a basis for the second part of the essay, where the effects of the terrorist attacks on the unipolar structure of the international system will be appraised, taking the reactions of the U.S. and the rest of the world to support the argument that unipolarity has been strongly but not unequivocally bolstered. For obvious reasons, the focus will be on the U.S. and its foreign policy. Shifts in the ways that the U.S. perceives and is likely to shape its hegemonic posture in international relations will be analyzed, and it will be argued that, although the United States is becom- 
ing a mature hegemon, the expectations of multilateralism in U.S. foreign policy are not likely to be fulfilled. The post-September 11 rapprochement between the U.S. and Russia will be dwelt upon to emphasize continuity in international relations and the accelerating impact of the terrorist attacks on the processes already on track before September 11. Finally, the effects on the major strands of international conflict will be assessed in this part, arguing that only one of them has been at least temporarily inactivated and that the Huntingtonian vision of the "clash of civilizations" remains inapplicable but potentially plausible.

\section{The Post-Cold War Context}

The post-Cold War international system, which has been evolving throughout the 1990s, has several key features built into it that are quite easily discernible in the fluid international environment. Understanding these features is necessary in the effort to detect changes of significance to the whole system after September 11. The first feature is unipolarity, which replaced the bipolar world of confrontation between the two superpowers, the United States and the Soviet Union. They were at the center of the two conflicting blocs of states during the Cold War, and acted as their consolidating forces as well as drivers of the international conflict generated by their ideological differences. The United States, by virtue of its economic, military, and political power, has been the only superpower in world affairs for the last decade, since the disintegration of the Soviet Union. Thus, almost by default, the U.S. emerged as the hegemonic state in the international system, capable of promoting its values and interests across the globe with unprecedented efficacy and virtually without any serious resistance from the system. The ideological dimension, built into the U.S.'s post-Cold War foreign policy and centered on the issues of human rights and freedoms as well as free markets, has been both appealing and intrusive. A number of countries previously not renowned for democratic practices have chosen the democratic path of development, associating themselves with the worldview promoted by the hegemonic power. Those remaining outside this trend have been subjected to strong external pressure, orchestrated by the U.S. and ranging from diplomatic and economic sanctions to military intervention. The last element of the American hegemonic position was a ring of credible and loyal allies, associating their security with U.S. guarantees and American ability to project military power globally, and directing their foreign policies in such a way as to ensure continuous U.S. presence and commitment. Thus, America has firmly established itself at the core of the international system, exercising significant influence on the system's processes and serving as its de facto arbitrator, seeking to preserve the stability of the system. The phenomenon was given the 
name of a new Pax Americana in the early 1990s by a number of authors (e.g., William Odom, Charles Krauthammer, etc.). ${ }^{4}$

Being in a position to pursue unilateral solutions as well as wielding enormous influence, the U.S. nevertheless remained reluctant to explicitly adopt and exercise its hegemonic posture in international relations, especially with respect to regional conflicts that required a prolonged military commitment and involvement in post-conflict reconstruction. Although having been conspicuous in the Middle East and Northern Ireland conflict resolution efforts, as well as restoring democracy in Haiti in 1994, the U.S. was hesitant to become fully involved in the Balkans in the early 1990s. This avoidance of the role of the "global policeman," which can be seen as being tailored to the hegemonic posture, was further reinforced by the failure of U.S. intervention in Somalia in 1993, and led the U.S. to ignore the genocide in Rwanda in 1994. At the same time, even such a selective or even half-hearted U.S. engagement sustained its hegemonic status and the unipolar structure of the international system, and evoked unfriendly and sometimes hostile reactions from some of the system's actors. To a greater or lesser degree, anti-American policies have become a determining characteristic of a number of states. An interesting aspect of this reaction is that some states, such as Russia or China, showed displeasure not about U.S. power per se, but about the unipolarity that this power created. Entertaining the concept of multipolarity, where the international system was envisaged as organized around several power centers that balanced each other and possessed their own spheres of influence, they moved to challenge the U.S. not on the basis of ideology, but for the global scope of its hegemonic outreach. At the same time, another group of states, mostly characterized as undemocratic, felt a far bigger threat from being exposed to the values and ideology that accompanied the U.S. hegemony than to the hegemony itself, and saw resistance as a prerequisite for the survival of their regimes and ideologies.

These two types of anti-American motivation can be found in mixture, as the case of China suggests. However, the latter motivation produced one of the most sustainable lines of international conflict during the last decade - the United States and its allies versus so-called "rogue states," such as Iran, Iraq, Syria, Cuba, North Korea, Sudan, or Libya. Containment of the rogue states, which have embarked on policies of acquiring weapons of mass destruction and sponsoring terrorism, has occupied a large proportion of the U.S. foreign and military policy agenda since the Gulf War in 1991, although the policy itself dates back to the years of the Cold War. Then overshadowed by and subordinated to the confrontation with the Soviet Union, this conflict has become one of the major priorities in the postCold War era. In addition, it falls into a more general trend of conflict between the democracies and undemocratic regimes, a trend which has re-asserted itself

\footnotetext{
${ }^{4}$ See J. Ann Tickner, "Re-visioning Security," in International Relations Theory Today, edited by Ken Booth \& Steve Smith (Cambridge: Polity Press, 1995), 183-184.
} 


\section{THE QUARTERLY JOURNAL}

during the last decade. Deriving legitimacy for its hegemony from the cause of spreading human rights and freedoms, and also by virtue of representing those values most robustly, the United States has appeared at the forefront of this standoff, reserving the right to intervene, on behalf of the international community and with its support, in internal conflicts where human rights violations were leading to the spread of violence and humanitarian disasters. The air campaign of NATO against Yugoslavia to stop the ethnic cleansing in its separatist province of Kosovo in 1999 heralded the full maturity that this doctrine had reached.

Moreover, once the destabilizing effects of internal conflicts to the international system have been acknowledged, the humanitarian justification of intervention to a great extent overlapped with the compelling need to prevent the internationalization of these domestic conflicts. In this respect, interventions into so-called "failed states," where the central government was barely functioning or not functioning at all and the hostilities between various factions or warlords led to massive human rights violations as well as regional instability, became yet another element woven into the broader framework of post-Cold War international conflict. Bosnia, Somalia, and Sierra Leone stand out as the most prominent examples of this form of intervention during the last decade. Failure in Somalia has made the United States lukewarm to this kind of intervention, especially if any potential resultant regional instability did not directly threaten the U.S. interests and humanitarian considerations prevailed. The Clinton Doctrine, articulated in 1994 by then-U.S. President Bill Clinton, specifically argued for the presence of national interests as a prerequisite to bring the U.S. into such conflicts. As a result, other nations had to take the lead in such missions (the U.K. in Sierra Leone, Australia in East Timor), which testifies to both the selective use of hegemonic power by the U.S. and their ability to set a standard for addressing challenges to the international system to be followed by others.

These three interweaving and overlapping facets of international conflict, with the United States more or less at their center because of the unipolar nature of the international system, are supplemented with the friction generated by the globalization process and its consequences. It manifests itself as social protest against the globalizing world, where disaffected groups challenge the social groups and commercial structures that are considered to be the winners of rapid technological, economic, and socio-political transformation, as well as the state governments and international institutions that are viewed as tools facilitating globalization. Globalization, perceived as a threat to the identities, welfare, and values of certain groups, provokes a backlash that sometimes turns into violence (e.g. the anti-globalization movement protests during the World Trade Organization summit in Seattle in 1999, or during the Genoa summit of G8 in 2001). It can

\footnotetext{
${ }^{5}$ See Hugo Slim, Military Humanitarianism and the New Peacekeeping: an Agenda for Peace? at www-jha.sps.cam.ac.uk/a/a015.htm (written 1995; accessed on May 17th, 2000).
} 
hardly be called an international conflict in the classical sense, since the challenge that brought about the conflict emanated not from state actors, but from social formations within the states themselves. However, born within the states, these movements became transnational in nature, transcended their own state's borders by targeting foreign governments, international organizations, and even other societies. Furthermore, this conflict had a propensity for translating itself into the inter-state rivalry between the rich, developed states and the poor, less developed countries that are vulnerable to the pressures of globalization and are confronted with having large segments of their societies unable to adjust to and capitalize on this process. In geographical terms, it has become common to draw the line of conflict between the North and the South (the rich North versus the poor South), which has replaced the East-West axis of the Cold War confrontation. The United States has emerged as the biggest beneficiary of globalization and, to a certain extent, its strongest driving force through the promotion of free trade and through its competitive advantage stemming from its technological leadership. According to Peter Van Ham, “... the swell of economic and cultural globalization is often seen as the USA's ultimate soft-power resource.' ${ }^{.6}$ Hence the U.S. has been one of the most prominent targets of the social discontent over globalization and a scapegoat for the plight of the underdeveloped states of the South.

The post-Cold War picture of international conflict presented above is neither exhaustive nor does it attempt to incorporate a vast array of theoretical approaches formulated in the last decade or so. Since the end of the Cold War, a number of conceptual visions on what future international conflicts will look like have been competing for recognition. In the current context, the one espoused by Samuel Huntington is worth mentioning. In the early 1990s, he argued that the ideological confrontation between the two superpowers was for a number of reasons being gradually replaced by a "clash of civilizations." He argued that, "the principal conflicts of global politics will occur between nations and groups of different civilizations." ${ }^{\prime}$ Huntington defined civilizations primarily as cultural entities and argued that there was an inherent friction between them, leading to violent conflicts in the regions where civilizations overlapped or came into direct geographical contact with each other. Armed conflicts in the Balkans, Trans-Caucasus, the Middle East, Kashmir, and other places were explained in these terms.

The Huntingtonian model has been criticized and contested on various grounds, especially for the less than reliable criteria used for defining "civilization" as well as for its tendency to see the clash of civilizations in some particular cases where it was absent in the origins of the conflict. However, Huntington's observations retain validity in what is perceived as a conflict between the West and the rest of the world. He argues that, "the West in effect is using international

\footnotetext{
${ }^{6}$ Peter Van Ham, "Security and Culture, or, Why NATO Won't Last" Security Dialogue 32:4 (2001), 398.

7 Samuel P. Huntington, “The Clash of Civilizations?” Foreign Affairs, Summer 1993.
} 
institutions, military power, and economic resources to run the world in ways that will maintain Western predominance, protect Western interests, and promote Western political and economic values. ${ }^{.8}$ This behavior provokes responses from those non-Western states and societies unwilling to accept and internalize Western values and beliefs such as liberal democracy or human rights. The four lines of conflict, outlined previously, can easily fit into this notion as its different strands. For instance, Huntington essentially explains the existence of "rogue states" as one of the forms of response to Western civilizational hegemony and expansion. Once again putting the dominant trend under the title "the West versus the Rest" can pose difficulties for the analysis of specific cases. But, flawed as it may be, Huntington's theory provides some valuable insights into the dynamics of international conflict and brings to the attention of academic discourse cultural differences as one of the ingredients feeding into the dynamics of international conflict. "The West versus the Rest" aspect encapsulates quite well what has been taking place in the unipolar international system under the hegemonic sway of the United States, although it does not necessarily carry sufficient explanatory power to help us understand all the frictions and conflicts in international relations. Cultural differences should not be viewed as the primary cause of conflicts, despite the fact that they do play their part in exacerbating the tensions over which conflicts erupt.

International relations have been evolving within the parameters of the unipolar international system and under the influence of the aforementioned tensions in it for the last decade. This rough outline of how the world looked prior to September 11 does not suggest, however, the presence of as much of the clarity and simplicity conducive to rational and effective decision-making that is necessary to address challenges and threats as it may seem to. The multidimensional character of international conflicts inevitably produced fluidity and ambiguity, making it difficult to prioritize policies and to come to grips with the whole complexity of the post-Cold War world and the direction it has been heading. For the U.S. in particular, this ambiguity raised a number of questions on what the nature of its hegemonic policy should be, whether the unipolarity could be sustained in a long term, where the U.S.'s national interests and priorities lie, and what the major sources of threats to them are. As a result, U.S. policy seemed to lack coherence and, in many instances, was reactive rather than proactive. Its remarkable feature was that the United States' reluctance and selective engagement in world affairs had continuously aroused fears among its allies over the possibility that the tremendous power of the U.S. would allow it to retreat into self-isolation from the world affairs in order to reduce the costs of being the world hegemon and, at the same time, to seek and impose unilateral solutions in cases where vital U.S. interests were threatened or challenged.

The policies of the new administration of President George W. Bush, who took

\footnotetext{
${ }^{8}$ Ibid.
} 
office in the beginning of 2001, aggravated these concerns, as the administration was clearly inclined to pursue unilateralist policy schemes. The plans to deploy the National Missile Defense (NMD) system, designed to protect the continental U.S. from missile attacks by hostile regimes, emerged as the ultimate manifestation of the "go-it-alone" approach. A string of decisions not to cooperate in, or even to actively undermine multilateral efforts in various fields perceived as inconsistent with U.S. national interests (such as the Kyoto Protocol on greenhouse gas emissions, strengthening the verification regime of the Biological and Chemical Weapons Convention, ratification of the Comprehensive Test-Ban Treaty, etc.) seemed to confirm these worrisome trends and stirred further controversies over the gap between actual U.S. behavior and the responsibilities inherent in the role of the global hegemon as perceived by the rest of the world. In this respect, the events of September 11 have indeed introduced more clarity to a vision of how the hegemon should behave and what kind of challenges should be given a higher priority. However, it can be easily noticed that the post-Cold War international system has not been shocked to such an extent so as to start shifting away from unipolarity, although it is less certain whether this pattern will endure in a long term, as will be suggested later. These observations, as well as the accompanying trends in international relations and characteristics of international conflict, will be elucidated in the second part of the article.

\section{The Attacks of September 11 and their Impact}

The attacks perpetrated against the hegemonic power of the unipolar world are inevitably bound to reverberate through the whole international system. September 11 was the first time in the post-Cold War era (or in the twentieth century, for that matter) that the United States was challenged with such destruction and hit at the heart of its financial and military power. Dramatic as they were, the attacks should not be assessed as the turning point at which the previous international system, together with the dynamics of international relations and international conflict built into it, ceased to exist and have been replaced by something entirely new. A strong case can be made to suggest that September 11 should be analyzed more in terms of continuity rather than drastic change.

\section{Unipolarity highlighted but not unequivocal}

First of all, the international system remains fundamentally unipolar. The attacks have done nothing to fundamentally undermine U.S. power (economic, financial, political, and military), its ability to project this power globally, or the dependence of the rest of the world on the United States, even if this was the original motive behind the attacks. On the contrary, these characteristics have become more significant, as a strong incentive for the United States to exploit more vigorously its unique position in the international system has appeared. A strong assertion of unipolarity was noticeable in the words of President Bush, aired during his 


\section{THE QUARTERLY JOURNAL}

address to the Congress in the aftermath of the attacks, where he framed the imperative for the world community by saying that "every nation, in every region, now has a decision to make. Either you are with us, or you are with the terrorists." Thus, little choice has been left for the rest of world but to rally behind the U.S. or bear the consequences of either indecision or opposition. The world reaction to the terrorist attacks followed this imperative word for word. The U.S. allies, driven by moral repulsion of the atrocities and a strong commitment to support the U.S. as well as by a shared threat perception, offered all possible assistance, as the activation of Article 5 of the NATO founding treaty on collective defense demonstrates.

Some states, such as Russia or China, responded along similar lines, but more out of expedience and pragmatic considerations, hoping to reap benefits such as legitimization of their domestic policies (Russia's war in the breakaway republic of Chechnya, for instance), more favorable treatment by the U.S. in the areas of trade and finance (especially for China) and, in the case of Russia, U.S. assistance in dealing with threats to its national security. Even some countries featured on the list of rogue states, such as Sudan, Libya, and Iran, felt compelled to condemn the attacks against their ideological enemy and, if not to cooperate, then at least to avoid obstructing in any way the U.S. response. All this reveals the extent to which U.S. policy has become central to world affairs and to which the world has become dependent on the United States. It can be concluded, therefore, that the events of September 11 have become yet another landmark, accentuating the unipolar nature of the international system.

On the other hand, certain echoes and manifestations appeared after September 11 that are reminiscent of the bipolar structure of the international system, as the history of the Cold War shows, and which may upset the above account. First is the sense of the overwhelming threat to the security and value system of American society, echoing the perception of the Soviet threat of the Cold War years. The terror of September 11 has created the same sense of profound insecurity, vulnerability, and uncertainty as the fear of nuclear attack by the Soviet Union, and the effort to redress this threat equally dominates the U.S. security and foreign policy agenda. Furthermore, a strong and powerful sense of the U.S. mission ensues both from the need to respond and from the freshly acute realization of the U.S. position in the international system as the only nation capable of delivering that response to protect the status quo. At the Asian-Pacific Economic Cooperation (APEC) summit in Shanghai, President Bush succinctly defined this new sense of mission claiming that "this conflict is a fight to save the civilized world."10

\footnotetext{
${ }^{9}$ Address to a Joint Session of Congress and the American People, September 20, 2001, at www.whitehouse.gov/news/releases/2001/09/20010920-8.html, accessed on December 14, 2001.

${ }^{10}$ See 'Defining the Challenge: Who Asked Mr. Bush to 'Save Civilisation'?" The Guardian, October 24, 2001.
} 
One can easily draw parallels with the Cold War, when the United States acted on behalf of the free world to fend off the communist ideological expansion.

Yet another aspect that echoes the bipolar confrontation is the renewed usage of the word "containment" to shape and define U.S. strategy, only this time it is aimed at containing the terrorist threat in general rather than any particular state actor. ${ }^{11}$ The impression of a non-coincidental parallel with the Cold War containment strategy is being strengthened by the warnings of the U.S. leadership that the U.S. as well as its allies should be preparing for a long haul in this struggle to contain terrorism. ${ }^{12}$ To push the parallel even further, it is obvious that the war on terrorism, just as the Cold War, will not see any continuous and sustained military action. Intelligence operations, covert action, and financial and law enforcement measures will probably be more important tools employed to cope with the threat than the standing military.

Finally, it is obvious that September 11 will be followed by a period of deep U.S. engagement and global activism, as the realization hits home that any unresolved regional conflicts or the continued existence of "failed states" will be a breeding ground for extremism and terrorist activities, and that eventually the United States will become their ultimate target yet again. Having dismissed the U.S. role in state and nation building prior to September 11, the current Bush Administration seems to be revising this approach as the military campaign in Afghanistan draws to a close. The emerging U.S. determination not to leave any vacuum for extremism to thrive thoroughly resembles the effort to be actively present in all regions as a part of the anti-Soviet strategy. The only element missing in this picture to complete the bipolar structure is the second pole of the international system. However, the pole could be conceptually constructed if one defines it not as an equally powerful hostile state with its own sphere of influence, but as an amorphous structure, comprised of the terrorist networks, the rogue states, and even large segments of some societies exercising strong anti-American sentiments, all united by ideology. President Bush has already shown his determination to add state actors along with the terrorist networks to the adversary's profile by declaring that "any nation that continues to support terrorism will be regarded by the United States as a hostile regime," 13 while carefully avoiding any allusions to the social dimensions of the conflict. In such a case, the notion of an asymmetric confrontation would apply, where one side is easily identifiable, well structured, organized, and has an obvious leader (the U.S.), while the other side remains more or less elusive, complex, and without the center of gravity inherent to the oppo-

\footnotetext{
${ }^{11}$ See Jim Hoagland, "America Can't Wage the Anti-Terror War Alone," The International Herald Tribune, January 14, 2002.

${ }^{12}$ See Tracy Grant, "Bush Braces Country for War," Washington Post, September 15, 2001.

${ }^{13}$ Address to a Joint Session of Congress and the American People, September 20, 2001, at www.whitehouse.gov/news/releases/2001/09/20010920-8.html, accessed on December 14, 2001.
} 


\section{THE QUARTERLY JOURNAL}

nent, but nevertheless is capable of inflicting significant damage to the interests of the adversary as well as keeping him mobilized and insecure while dictating the level of individual and social loyalties that are to be reckoned with.

This account would certainly be a huge departure from the conventional and modest assessment of the consequences of the events of September 11 for the international system. However, the transition from a unipolar to a bipolar world is only a possibility, rather than the current reality, and can materialize only if this new definition of what constitutes the other pole in the international system is universally accepted, if U.S. resources become so overextended as to lead the world to be less dependent on the U.S. as an arbiter and the source of security, and if a situation arises where loyalty to hegemonic U.S. leadership is easily traded and shed. The latter possibility has already been noted by the U.S. Deputy Secretary of Defense Paul Wolfowitz, who observed that, "One of the difficult things in the next few months is going to be establishing which of our allies of convenience ... can become real allies over the longer term .... and which ones are going to just switch sides." ${ }^{14}$ It is also important to note that the application of the strategies of the bipolar system can be carried out in the unipolar world all the same, as the containment of the rogue states through the mechanisms of international sanctions during the 1990s shows. This may especially be the case given that the key policymakers of the Bush administration are much more familiar with the strategies of the Cold War and are more eager to employ them rather than innovate. Being mindful of the reactions to September 11 within the international system discussed earlier, it would be premature to announce the demise of unipolarity, although the aspects of post-September 11 developments highlighted here should lead the analyst to be more flexible and open-minded in future categorizations. Enthusiastic use of techniques and rhetoric intrinsic to the bipolar structure of the international system by the Bush administration can become a self-fulfilling prophecy in the end.

\section{The maturing hegemon and international relations}

In the area of international relations, one can discover a mix of change in and continuity of the pre-September 11 patterns of interaction. The most significant change perhaps should be associated with the way that the hegemonic power (the U.S.) has been acting since the terrorist attacks. Having been averse to the role of global policeman and hesitant to commit itself wholeheartedly to building security and prosperity wherever such a need arose during the last decade, the United States seems to have started interpreting its position in world politics more robustly, appreciating that selective engagement, let alone self-isolation, cannot prevent hostile acts and challenges. As the U.S. Secretary of Defense Donald H.

\footnotetext{
${ }^{14}$ Dao, James, and Schmitt, "U.S. Hawk Hints Iraq Won't Be Next Target," The International Herald Tribune, January 9, 2002.
} 
Rumsfeld wrote: "Forget about 'exit strategies'; we're looking at a sustained engagement that carries no deadlines." 15 It is now more likely that U.S. engagement will be far deeper and wider than previously would have been the case, even in places where U.S. interests seem to be largely absent. The conflict between India and Pakistan over Kashmir, the Muslim insurgency in the Philippines, the failure of states in places such as the Democratic Republic of Congo or Somalia, the Palestinian intifada, and many other developments and events are set to receive or are already receiving a far greater amount of U.S. attention than they did prior to September 11. Essentially, the United States is undergoing a transformation from being a reluctant into being a mature hegemon, ready to throw its power and resources into troublesome spots where opportunities for opponents of the U.S. to undermine American interests present themselves. The declared readiness on the part of the U.S to stay in Afghanistan and assist its newly formed government as long as it takes to build a viable state can serve as a precursor of the revised U.S. approach to its international responsibilities. ${ }^{16}$

The willingness to sustain global engagement, though, can still wither away as a sense of crisis and pressure for action subside. Some analysts have expressed their doubts over whether such a transformation will be sustained. As Professor Niall Ferguson of Oxford University rather bluntly puts it: "The U.S. has the resources; but does it have the guts to act as a global hegemon and make the world a more stable place?"17 Meanwhile, the expected reversal from unilateral to multilateral methods of formulating and implementing U.S. policies, ${ }^{18}$ which implies more consensus building and appreciation of the interests of other states, has failed to materialize. The broad anti-terrorist coalition that the U.S. sought to assemble before taking any military action represents the pursuit of a theoretical imperative of isolating the enemy diplomatically and strategically rather than introducing multilateral modes of policymaking and implementation. To be fair, multilateral elements have indeed emerged in U.S. policy. Reinvigorated interest in the opportunities offered by the United Nations, largely absent until recently, can be presented as an example, ${ }^{19}$ and concern over not alienating valuable allies in the war against terrorism is another.

\footnotetext{
${ }^{15}$ Donald H. Rumsfeld, “A New Kind of War,” The New York Times, September 27, 2001.

${ }^{16}$ See The White House Report The Global War on Terrorism: The First 100 Days, at http://www.whitehouse.gov/news/releases/2001/12/100dayreport.html, accessed on January 15, 2002.

${ }^{17}$ See the contribution by Prof Niall Ferguson to the joint Guardian-RUSI conference on New Policies for the New World, published in The Guardian, October 31, 2001.

${ }^{18}$ See Moises Naim, "Even A Hegemon Needs Friends and Allies," Financial Times, September 14, 2001.

${ }^{19}$ See Remarks by the President to United Nations General Assembly, November 10, 2001, at http://www.whitehouse.gov/news/releases/2001/11/20011110-3.html, accessed on January 15, 2002 .
} 


\section{THE QUARTERLY JOURNAL}

But the overall trend of the United States being ready to consult partner nations while seeking to avoid any of the constraints that multilateral action usually entails, especially in the military realm, continues unabated, just as it stood prior to September 11. Furthermore, the policy of eluding or even undermining some multilateral binding arms control agreements, seen as an undesirable constraint on U.S. freedom of maneuver and set on track during 2001 or even earlier, remain firmly in place. The United States further refuses to ratify the Comprehensive Test-Ban Treaty and has ruined any chances of making the Biological and Toxic Weapons Convention more credible through strengthening its verification regime, ${ }^{20}$ despite the risk of upsetting its allies and creating the atmosphere of double standards so readily pointed out by its foes. The same holds true for the U.S. determination to dispense with the 1972 Anti-Ballistic Missile (ABM) Treaty, viewed by former adversaries and current allies alike as a cornerstone of world strategic stability, in order to pave the way for the deployment of the NMD system. President Bush has already announced that U.S. withdrawal from the treaty is imminent. In this instance, the U.S. has not grown any more sensitive to the concerns of the international community after September 11. Instead, it is exploiting the moment to make the cause for a new strategic framework stronger and more acceptable. Relations with Russia perhaps best exemplify the continuity of the same pattern of interaction as existed prior to September 11.

U.S. relations with Russia have been developing as an uneasy mixture of cooperation and disagreement for the last decade. A number of issues, such as NATO enlargement and the Alliance's "out-of-area" operations as in the Balkans, the NMD system and the fate of the ABM Treaty, non-proliferation, Russia's two wars in Chechnya, and its meddling in the so-called "Near Abroad," have been poisoning the new agenda of bilateral relations almost constantly. With the second President Bush taking office, it was widely expected that U.S. policy towards Russia would be far more assertive and less conciliatory than under his predecessor. As Russia's President Vladimir Putin was also seen as a person preferring a tough stand in foreign policy to regain Russia's lost status in international affairs, it was tempting to conclude that the two states would slide back into permanent confrontation, although less dangerous than during the Cold War, but nevertheless sufficiently bruising and damaging to prompt concerns.

Post-September 11 developments seemed to render those concerns irrelevant. Both states have found a common uniting issue, since the terrorist threat has been long regarded by Russia to be the most dangerous threat to its national security. Given that shared threat perception is always a starting point for building an alliance, Russia's determination to join the anti-terrorist effort can be interpreted as drawing it closer to the West. Some Russian officials went so far as to ponder once again the possibility of Russia acceding to NATO and to tone down objec-

\footnotetext{
${ }^{20}$ See "Bush's Hang-ups," The Economist, December 15-21, 2001.
} 
tions to the accession of the Baltic States into the Alliance. ${ }^{21}$ NATO also moved to reshape and upgrade its relations with Russia, and to make them better reflect the post-September 11 realities. $^{22}$ More importantly, Russia has become an indispensable ally of the United States during the campaign in Afghanistan, sharing intelligence and expertise on the region and waiving objections to the U.S. military presence in Central Asia, perceived as Russia's backyard in terms of influence and strategic interests. Washington, in turn, was quick to suspend criticism of Russia's military campaign in Chechnya, acknowledging that at least some parts of Russia's argument for military action were valid and legitimate. ${ }^{23}$ This was followed by the announcement of bilateral cuts in nuclear arsenals during the summit in Texas in November 2001, applauded as heralding a new era in the strategic relations of the former Cold War adversaries and laying ground for a new strategic framework while addressing Russia's anxieties over U.S. intentions to abolish the ABM Treaty. ${ }^{24}$ Although not abandoning their opposition to the NMD, Russia's officials sound more realistic and more assured on this issue than previously. ${ }^{25}$

Positive as they are, these developments, however, are neither entirely new nor are they rooted solely in the events of September 11. The dawn of a new era in strategic relations between Russia and the United States was declared during the June summit between Bush and Putin last year in Ljubljana, Slovenia. On the same occasion, both sides pledged to work on putting substance into the envisioned framework of their strategic relations. ${ }^{26}$ In a similar vein, Putin has been softening Russia's vehement opposition to further NATO enlargement for some time, replacing threats of a commensurate response with arguments questioning the rationale of the enlargement. ${ }^{27}$ Russia even failed to come up with its usual counter-statement after President Bush had outlined his vision of Europe "free and united" in his endorsement of the NATO enlargement project in Warsaw, Poland, last year. ${ }^{28}$ Furthermore, it must be mentioned that Russia has been

\footnotetext{
${ }^{21}$ See "Why Not Accept Russia Into NATO? Interview with Sergei V. Stepashin," Business Week Online, September 21, 2001, on Johnson's Russia List (JRL), Issue 5454, at http://www.cdi.org/russia/johnson/5454-7.cfm, accessed on January 15, 2002.

${ }^{22}$ See Peter Finn and Peter Baker, "NATO and Russia Reinventing Relationship," Washington Post, November 15, 2001.

${ }^{23}$ See Ana Politkovskaya, "Remember Chechnya," Washington Post, November 14, 2001.

${ }^{24}$ See David E. Sanger, "Bush and Putin Agree to Reduce Stockpile of Nuclear Warheads," The New York Times, November 14, 2001.

${ }^{25}$ See Michael Wines, "Facing Pact's End, Putin Decides to Grimace and Bear It," The New York Times, December 14, 2001.

${ }^{26}$ See Angela Charlton, "Bush, Putin Face Diplomatic Hurdles," Associated Press report on Johnson's Russia List (JRL), Issue 5037, June 18, 2001, at http://www.cdi.org/russia/johnson/5307.html, accessed on July 10, 2001.

${ }^{27}$ See "Putin Softens Tone on Baltic Quest For NATO," Jamestown Foundation Monitor, September 6, 2001 on CDI Russia Weekly at http://www.cdi.org/russia/170.html, accessed on September 9, 2001.

${ }^{28}$ See Remarks by the President in Address to Faculty and Students of Warsaw University, Warsaw,
} 


\section{THE QUARTERLY JOURNAL}

already talking of not ruling out the possibility of joining the Alliance at some time in the future, although tailoring this idea to a set of conditions deemed unacceptable by the West. Russia's drift towards the West, therefore, could be noticed already before the events of September 11. A more co-operative agenda had been unfolding, without the effects of the terrorist attacks. Many observers and policy analysts, taking note of the pragmatic nature of Putin's policies, seem to have somewhat underestimated his pro-Western credentials. Meanwhile, after September 11, Putin has been taking stock of the pro-American sentiment in the Russian society and has sought to overcome the hard-line conservative elements in Russia's establishment by redefining Russia's interests in order to strike a chord with the West. ${ }^{29}$

The U.S. has also utilized the moment to give fresh momentum to the dynamics set into motion during 2001. Both sides have reached an understanding of where the commonality of their interests lies, which was blurred by mutual disagreements and suspicions before the terrorist attacks. The events of September 11 have only accentuated the ongoing change in bilateral relations and helped to remove the obstacles to the process of rapprochement on both sides. The assessment by the U.S. Secretary of State Colin Powell that September 11 "did not start something, it accelerated" 30 is very much valid in the post-September 11 state of U.S.-Russian relations, and perhaps is applicable in international relations in general. The way that September 11's events are influencing the post-Cold War patterns of international conflict is somewhat more complex, but nevertheless their lines are not being redefined as dramatically as may have been expected. The next part of the essay will dwell upon the impact of September 11 on major cleavages in the international system.

\section{Change and continuity in international conflict}

On September 11, three lines of international conflict out of four seem to have blended together into one shocking blow to the U.S., the state situated at the very core of the international system that emerged as a node where those lines of conflict intersect. Firstly, the Al-Qaeda terrorist network, spreading over 60 states and born out of a pathological hatred of the United States as a power that allegedly is seeking to destroy Islam as a cultural and religious phenomenon and to subjugate the Muslims, exemplifies very well the by-products of the globalization process and its accompanying frictions. Osama bin Laden personifies those unable to accept the post-modern way of life and the social values brought about by globaliza-

\footnotetext{
Poland, June 15, 2001, at http://www.whitehouse.gov/news/releases/2001/06/20010615-1.html, accessed on January 15, 2002.

${ }^{29}$ See Michael McFaul, "Putin's Risky Turn Westwards," The Christian Science Monitor, November 9, 2001.

${ }^{30}$ See "U.S. and Russia to Complete Talks on Arms Control Pact," The New York Times, December 11, 2001.
} 
tion, who react with anger and destruction at being pushed into marginality and irrelevance in the contemporary world. ${ }^{31}$ In a way, anti-globalization protesters causing havoc in the streets during the WTO or G8 summits and al-Qaeda terrorists represent two sides of the same coin in terms of the origins of their discontent. Also, just like the protesters on the streets, the terrorists skillfully capitalize on open communication, free movement of finances, and the new technologies that are sustaining globalization in their attack on the state that embodies globalization itself, and accomplished this by selecting targets symbolizing the financial and commercial as well as military might of the U.S.-dominated world. Furthermore, they managed to strike a chord with the anxieties and sensitivities of many societies in the Muslim world, unveiling the tensions created in those societies by modernization and exposure to the effects of globalization. ${ }^{32}$ Without going into detail and leaving the roots of terrorism for other inquiries to explore, it is enough to mention that the social and ideological cleavages in the international system brought into being by globalization are strongly present behind the September 11 attacks.

Secondly, the "rogue states versus the United States" line also manifests itself here, as the former are long suspected by the latter of sponsoring and supporting international terrorism. The presence of this conflict behind the terrorist attacks is obvious despite the fact that some of the rogue states were quick to issue condemnations of the atrocities. At the very early stage of the war on terrorism, the U.S. administration made it clear that this connection would be central to the U.S. anti-terrorist strategy. During his address to Congress, President Bush stated that, "any nation that continues to harbor or support terrorism will be regarded by the United States as a hostile regime." Arguments within the Bush Administration over whether Iraq — one of the most prominent pariah states-should be the next target after Afghanistan in the anti-terrorist campaign, have further reinforced the perception that the terrorist attacks are closely associated with the existence of the rogue states. ${ }^{33}$ The failed states also inevitably come into play in the analysis, as Afghanistan constituted the ground for recruiting and training terrorists and the physical base of the al-Qaeda leadership. Mostly neglected since the failure to restore order and governing structures in Somalia, these failed states turned out to be the safe haven for the training and operational activities of the terrorist network. Afghanistan has immediately become a target of the U.S. war on terrorism, and Somalia as well as another state balancing on the edge of failure, Yemen, have been named to become likely targets of the anti-terrorist action of the U.S. ${ }^{34}$ A

\footnotetext{
${ }^{31}$ See Aryeh Neier, "Warring Against Modernity," Washington Post, October 9, 2001.

${ }^{32}$ See Thomas L. Friedman, "One War, Two Fronts," The New York Times, November 2, 2001.

${ }^{33}$ See Martin Woollacott, "Saddam Will be the Next U.S. Target, One Way or Another," The Guardian, November 16, 2001.

${ }^{34}$ See David B. Ottaway and Thomas E. Ricks, "Somalia Draws Anti-Terrorist Focus," Washington Post, November 4, 2001.
} 


\section{THE QUARTERLY JOURNAL}

sober realization by the U.S. that the existence of failed or weak states is not favorable to U.S. interests simply because it can further stimulate the terrorist threat and, therefore, cannot be ignored, will shape the American strategy for the foreseeable future.

Thus three lines of international conflict, recognizable well before September 11 and clearly having had some role leading to the terrorist attacks, are likely to remain in place. The only cleavage that has been obscured by September 11 is the one between the democracies and undemocratic regimes that for various reasons do not qualifying for "rogue state" status. Pakistan and the states of Central Asia serve as the best examples of how undemocratic regimes have ceased to be a trigger for conflict and have turned into co-operative partners. Pakistan, widely regarded as having been gradually slipping into becoming a rogue state or even a failed state, or both, under the rule of General Pervez Musharraf, is now one of the most valuable U.S. allies. ${ }^{35}$ The United States seems to be ready to tolerate undemocratic regimes as long as they remain loyal to the U.S. in its war on terrorism and provided that these regimes retain a degree of control over their territories and populations necessary to prevent the rise of extremism and the development of new terrorist cells. Meanwhile, as a result of the changed U.S. attitude, the authoritarian rulers can enjoy the newfound legitimacy of their repressive policies, which, before September 11, they described as "fighting terrorism" only to be met with mockery from the West. ${ }^{36}$ It remains to be seen whether turning a blind eye to the undemocratic practices in other states for the sake of strategic co-operation will be a short-term U.S. strategy or a long-term trend, as the calls to prepare for a long haul may suggest. One note of caution is that such an approach during the Cold War produced all sorts of trouble for policymakers in the post-Cold War era, including a legacy of anti-Western sentiment in many societies.

One of the biggest fears of the international community, though, was that the U.S. response to the terrorist acts would indeed validate the Huntingtonian model of international conflict by turning the whole struggle into a clash of civilizations, between the U.S.-led Western world and the Islamic world. At the outset of the bombing campaign in Afghanistan, the argument that the United States was punishing an entire Muslim society for the atrocities perpetrated by a group of criminals and that it would antagonize the whole Muslim world were at the core of criticism of the U.S. strategy. ${ }^{37}$ Signs of outrage, spreading through the Muslim world, over the bombing and the civilian casualties were apparent as was indicated by the demonstrations in Pakistan or the lack of endorsement by the Gulf States, who came under pressure from their societies not to support the campaign $3^{3} \mathrm{An}$

\footnotetext{
${ }^{35}$ See Bill Keller, Bill, "The World According to Colin Powell," New York Magazine, November 26, 2001.

${ }^{36}$ See "The New New World Order?" The Economist, October 5-12, 2001.

${ }^{37}$ See Malise Ruthven, “This Man May Become Our Nemesis," The Guardian, October 10, 2001.

${ }^{38}$ David Hirst, "The West Ignores Arab Resentment at Its Peril," The Guardian, October 9, 2001.
} 
unfortunate parallel evoked by President Bush between the Crusades and the current war on terrorism was not at all helpful in presenting the campaign as an effort directed against "rogue" elements and not as a manifestation of a long-harbored Western hostility to the Muslims. ${ }^{39}$ Talk of the West, and the United States in particular, exploiting the opportunity provided by September 11 to unleash its power against the Muslim world has become common among Muslims. ${ }^{40}$ Given that any war tends to harden attitudes and push them to the extremes, the terrorist attacks may well induce proliferation and consolidation of anti-Muslim and anti-Western sentiments in Western and Muslim societies respectively, thus pitting them against each other and bringing about something resembling the clash of civilizations.

However, this remains a very remote possibility, since the U.S. and its allies have made every effort to isolate and discourage any domestic anti-Muslim hysteria as well as to win the hearts of the Muslims by disassociating Osama bin Laden's cause from their grievances. As a result of a relatively measured and selfrestrained U.S. response and a carefully mastered public relations campaign to convince Muslim societies of the absence of any broader anti-Muslim motivation behind this campaign, the view that this is a war between Western and Islamic civilizations is confined to the margins of those societies. ${ }^{41}$ The commitment to stay in Afghanistan and help to rebuild the country destroyed by decades of civil war served very well to strengthen this message of assurance. Nonetheless, September 11 underlines the fact that perceptions can be pushed by terrible events into such directions as to turn theories currently lacking any credibility into a dominant explanation of why the conflict is taking place. The terrorist attacks and Osama bin Laden's following propaganda to unite the Muslims behind his religious cause to destroy America and other "infidels" may have given Huntington's model more relevance than it has had before in the eyes of many, even though the terrorist attacks can be better explained in terms other than the clash of civilizations. It requires and will continue to require a sustained and carefully crafted policy and course of action to steer both sides away from the overwhelming perceptions of confrontation between Western and Islamic civilizations outlined by Huntington. Huntington was not entirely right prior to September 11, and he remains such afterwards, but he still can become right as the war on terrorism continues.

\section{Conclusions}

Provoked by numerous claims that the terrorist attacks against the United States on September 11 have dramatically changed the world, this article explored a moderate course of interpreting the importance of these events to world affairs. Taking

\footnotetext{
${ }^{39}$ See Peter Ford, "Europe Cringes at Bush 'Crusade' Against Terrorists," The Christian Science Monitor, September 19, 2001.

${ }^{40}$ Jonathan Freedland, "The War Bin Laden Has Already Won," The Guardian, October 10, 2001.

${ }^{41}$ See Stephen Fidler, "Washington Wages a War of Diplomacy," Financial Times, November 8, 2001.
} 


\section{THE QUARTERLY JOURNAL}

three interrelated dimensions - the international system, international relations, and international conflict - as the analytical framework, it endeavored to place September 11 into the general post-Cold war context that emerged during the preceding decade. Preoccupied with the question whether September 11 should be conceptualized as a trigger of change or a symptom of what has been evolving for some time, the analysis leads to accepting the latter interpretation. Certainly, this does not imply that nothing at all has changed. Our perceptions and understanding of the terrorist threat, of the destructiveness it can bring about and of the means which terrorists can use to exploit our vulnerabilities, have acquired completely new dimensions and, more importantly, are now rooted in a terrible experience rather than theoretical models and hypothetical contingencies. But the course of world politics, with some minor adjustments and some new probabilities, remains a continuation of the pattern set prior to the attacks. The unipolar international system is not showing any signs of collapsing, even though some strategies and characteristics of the bipolar world have appeared, causing one to ponder the theoretical possibility of neo-bipolarity and the need to revise our notion of the system's pole.

The world-wide rallying behind the United States underscores the extent to which the U.S. has positioned itself as the central power in the international system, ensuring its functioning, stability, and security. The U.S. remains a hegemon in international relations, dictating the rules of the game as well as the nature of responses to challenges from within the system. Its influence, interests, and policies continue to formulate imperatives for the other actors. Only this time, reluctance to exercise this hegemonic influence is giving way to a wider and deeper global engagement to prevent further challenges like the one on September 11, bringing the U.S. closer to the role of "global policeman" that it has sought to avoid but has come to realize it has no choice but to assume. The hopes of multilateralists have been dashed, however, and the expected shift towards multilateral decision-making in international relations has failed to take place, as the U.S. remains unwilling to accept any external constraints, although it does display more readiness to consult before making decisions.

Finally, most of the strands of international conflict remain in place after September 11. Pressure upon the "rogue states" will persist and will even intensify. Interventions in failed states will be as instrumental to ensuring security of the international system as never before. And globalization will continue generating social and economic tensions with implications for international relations. Only those who believe that further expansion of democratic values and practices can guarantee peace and stability will be temporarily upset as the United States seeks allies in its war on terrorism, whether they are democratic or not. And the Huntingtonian clash of civilizations, which was not driving international conflict before September 11, is not becoming a reality, although its coming into being is another probability exposed by the terrorist attacks. The events of September 
11 are symptomatic of the trends and developments that preceded them. They accentuate the characteristics of the post-Cold War setting and have also accelerated some processes, such as rapprochement between Russia and the U.S., by making their rationale more obvious. Thus, these atrocities are not a new departure point from which we should start counting the days of a post-post-Cold War era. Certainly, the continuing war on terrorism may work some changes, but it is rather a war that will consolidate the current world order instead of installing a new one. Most probably President George W. Bush will not enter history along with Woodrow Wilson or Franklin D. Roosevelt as an architect of a new world order, despite his merits for fighting terrorism. 


\section{Bibliography}

Dao, James, and Eric Schmitt. "U.S. Hawk Hints Iraq Won't Be Next Target." The International Herald Tribune (2002).

Fidler, Stephen. "Washington Wages a War of Diplomacy." Financial Times (2001).

Fidler, Stephen. "Washington Wages a War of Diplomacy." Financial Times (2001).

Ford, Peter. "Europe Cringes at Bush 'Crusade' Against Terrorists." The Christian Science Monitor (2001).

Freedland, Jonathan. "The War Bin Laden Has Already Won." The Guardian (2001).

Grant, Tracy. "Bush Braces Country for War." Washington Post, (2001).

Hoagland, Jim. "America Can't Wage the Anti-Terror War Alone." The International Herald Tribune (2002).

Woollacott, Martin. "Saddam Will be the Next U.S. Target, One Way or Another." The Guardian (2001). 